\title{
Financial and non-financial performance measures and managerial short-term orientation: the interactive effect of performance targets
}

Citation for published version (APA):

Moers, F. (2000). Financial and non-financial performance measures and managerial short-term orientation: the interactive effect of performance targets. METEOR, Maastricht University School of Business and Economics. METEOR Research Memorandum No. 053 https://doi.org/10.26481/umamet.2000053

Document status and date:

Published: 01/01/2000

DOI:

10.26481/umamet.2000053

Document Version:

Publisher's PDF, also known as Version of record

Please check the document version of this publication:

- A submitted manuscript is the version of the article upon submission and before peer-review. There can be important differences between the submitted version and the official published version of record.

People interested in the research are advised to contact the author for the final version of the publication, or visit the DOI to the publisher's website.

- The final author version and the galley proof are versions of the publication after peer review.

- The final published version features the final layout of the paper including the volume, issue and page numbers.

Link to publication

\footnotetext{
General rights rights.

- You may freely distribute the URL identifying the publication in the public portal. please follow below link for the End User Agreement:

www.umlib.nl/taverne-license

Take down policy

If you believe that this document breaches copyright please contact us at:

repository@maastrichtuniversity.nl

providing details and we will investigate your claim.
}

Copyright and moral rights for the publications made accessible in the public portal are retained by the authors and/or other copyright owners and it is a condition of accessing publications that users recognise and abide by the legal requirements associated with these

- Users may download and print one copy of any publication from the public portal for the purpose of private study or research.

- You may not further distribute the material or use it for any profit-making activity or commercial gain

If the publication is distributed under the terms of Article $25 \mathrm{fa}$ of the Dutch Copyright Act, indicated by the "Taverne" license above, 


\title{
Financial and Non-financial Performance Measures and Managerial Short-Term
} Orientation: The Interactive Effect of Performance Targets*

\section{Frank Moers}

\author{
Maastricht University \\ Faculty of Economics and Business Administration \\ MARC / Department of Accounting \& Auditing \\ P.O. Box 616 \\ 6200 MD Maastricht \\ The Netherlands \\ f.moers@berfin.unimaas.nl
}

\begin{abstract}
MARC Working Paper
MARC-WP/3/2000-15
\end{abstract}

* I gratefully appreciate the comments made by my thesis advisors Willem Buijink, Frank Hartmann, and Ken Merchant. I am further grateful for comments and suggestions made by Robert Chenhall and seminar participants at the accounting colloquium of Maastricht University, the Second EIASM Conference on New Directions in Management Accounting, Brussels, and the 24th Annual EAA Conference in Athens. 


\section{INTRODUCTION}

The number of firms using non-financial performance measures for incentive purposes is increasing (Banker et al. 2000). Although there are a number of reasons why firms use nonfinancial performance measures, the primary reason is that some of them are leading indicators of financial performance (Kaplan and Norton 1992; 2001). Non-financial performance measures therefore provide managers with incentives to improve long-term financial performance. Financial performance measures, on the other hand, are predominately 'backward-looking' and lack predictive ability to explain future performance and therefore provide managers with incentives to improve short-term financial performance.

Both the practitioner literature (e.g., Kaplan and Norton 1992) and the theoretical literature on agency theory (e.g., Feltham and Xie 1994; Hemmer 1996) emphasize that nonfinancial performance measures change the effort allocation of managers, in the sense that these managers become more focused on the long-term impact of their actions. This implies that non-financial performance measures reduce the short-term orientation of managers, where managerial short-term orientation is defined in this paper as an orientation towards short-term financial results. Consequently, 'short-term incentives' imply incentives to improve short-term financial results, while 'long-term incentives' imply incentives to improve long-term financial results. However, despite the increased use of non-financial performance measures and the above 'claims', there is only little empirical evidence of the effects of these performance measures on the effort allocation of managers.

Furthermore, the accounting literature on incentives predominately focuses on the use and effects of performance measures and neglects another important component of incentive systems, i.e., performance targets (Ittner and Larcker 2000). Firms usually set explicit targets for managers and evaluate performance compared to target (Merchant et al. 2000). The type of target used can have a significant impact on managerial behavior. For example, Merchant 
et al. (2000) state that the effect of incentives is likely to be dependent on performance target difficulty. Alternatively, more difficult targets increase the risk the managers have to bear and less difficult targets may be the outcome of the trade-off between incentives and risk sharing when managers are risk averse (Merchant and Manzoni 1989). However, the empirical evidence of the use and effects of difficult performance targets in general is limited and no empirical evidence exists with respect to the use and effects of non-financial performance targets.

This paper contributes to the literature in three ways. First, it examines the incentive effects of both performance measures and performance targets and the linkages between these two components of the incentive system. Second, it tests the theoretical claim that nonfinancial performance measures provide subordinate managers with incentives to be longterm oriented. Finally, it examines the role of risk aversion in setting performance targets.

The empirical results show that the short-term orientation of subordinate managers increases (decreases) with the difficulty of financial (non-financial) performance targets but is not related to the use of either financial or non-financial performance measures for incentive purposes. Further, the difficulty of financial (non-financial) performance targets increases with the use of financial (non-financial) performance measures for incentive purposes, which suggests that performance measures have an indirect effect on managerial short-term orientation. Finally, the relationship between the use of performance measures and performance target difficulty is moderated by the risk aversion of the manager. That is, the relationship is less positive the higher the manager's risk aversion, which implies that superiors take the risk imposed on the manager into account when setting targets.

The remainder of this paper is organized as follows. In section II, I provide a theoretical background and develop hypotheses. In section III, I discuss the sample selection 
and data collection. In section IV, I present the empirical results and perform sensitivity analyses. Finally, I provide a summary and conclusion in section V.

\section{HYPOTHESIS DEVELOPMENT}

The main purpose of a control system is to align the goals of managers with those of the organization. One way to achieve this is through the design of incentive contracts. In general, incentive contracts consist of three primary elements (Merchant 1989): (1) performance measures, (2) performance targets, and (3) rewards. Each of these elements has an effect on the type of incentives provided to managers. In the following, I focus on the incentive effects of performance measures and performance targets that are used to determine different types of rewards, such as salary increases, bonuses, and promotion.

\section{Performance measures}

The design of incentive contracts, and the use of performance measures in these contracts, is the basic problem addressed by agency theory. In general, agency models analyze the situation in which a principal designs an incentive contract to motivate a risk and workaverse agent to provide effort. These incentive contracts are traditionally based on one or more noisy measures of performance. The assumption underlying these agency models is that the incentive contract and, more specifically, the performance measures used affect the agent's behavior. That is, the agent directs his attention to those aspects of the job that are being measured (Holmström and Milgrom 1991; Feltham and Xie 1994). Furthermore, increasing the incentive payment will lead the agent to exert more effort. As a result, agency theory predicts that the performance measure used for incentive purposes determines the direction of effort by the agent and that the incentive weight determines the amount of effort provided by the agent. This means that the use of incentive contracts will lead to higher effort levels and increased performance on those dimensions that are being measured. 
The findings in the empirical accounting literature on the effects of incentive systems are consistent with the agency predictions. For example, Banker et al. (1996), Wallace (1997), and Banker et al. (2000) all find that (measured) performance increases after the implementation of an incentive plan and that the decisions made by management are consistent with the incentives provided (Wallace 1997). Further, the empirical accounting literature pays a considerable amount of attention to the effects of earnings-based incentive plans on earnings management. In general, the studies by Healy (1985), Gaver et al. (1995), and Holthausen et al. (1995) provide mixed evidence with respect to the extent to which earnings-based incentive plans provide CEOs with incentives to make accrual decisions that maximize their bonus. Guidry et al. (1999) provide a more powerful test by examining earnings management by business-unit managers using business-unit-level data. Their results are consistent with the hypothesis that business-unit managers manipulate earnings to maximize their bonus. Similarly, Merchant's (1990) study of profit center managers indicates that the use of financial controls provides managers with incentives to be short-term oriented and to manipulate earnings by accelerating profits. In general, the empirical literature substantiates the agency prediction that 'what you measure is what you get'.

\section{Performance targets}

Performance targets are a part of the incentive system that is neglected in basic agency models. Traditionally, the outcome of an agency model presents an optimal incentive contract based on some measure of performance and the agent is told to 'do his best'. The behavioral literature on goal setting, however, indicates that goals have significant effects on behavior and performance. Goal setting theory predicts that when goals become more difficult, performance increases and that specific, hard goals lead to a higher level of performance than vague goals, such as ‘do your best' or no goals at all (Locke an Latham 1990). ${ }^{\square}$ The primary mechanisms that ensure that goals improve performance are the so-called universal task 
strategies, which consist of (1) direction of attention, (2) effort, and (3) persistence. First, goals direct attention to those activities for which goals have been assigned. Activities for which no goals have been assigned are interpreted as less relevant and the attention of the individual is therefore focused on goal-relevant activities. Furthermore, more specific goals make it easier for individuals to direct their attention than more general goals. Second, assuming sufficient ability, the more demanded from an individual, i.e., the more difficult a goal, the greater the expended effort. Third, given goal commitment, individuals continue to expend effort until the assigned goal is achieved. That is, goals lead to a persistence of effort over a certain period of time, where more difficult goals lead to greater persistence and thus higher performance.

The empirical accounting literature only pays a limited amount of attention to the effect of target setting on performance and managerial behavior (Ittner and Larcker 2000). Most of the evidence to date stems from experimental studies, which find results consistent with goal setting theory, i.e., more difficult targets increase performance (e.g., Chow 1983; Hirst and Yetton 1999). Using a survey questionnaire methodology, Simons (1988) shows that difficult budget goals increase firm performance, while Van der Stede (2000) finds that budgetary slack increases managerial short-term orientation. ${ }^{2}$ Overall, the results of the empirical studies investigating target setting indicate that the degree of target difficulty affects performance and managerial behavior.

\section{Hypotheses}

The discussion above shows that both the type of performance measure used and the difficulty of the target associated with this performance measure have an effect on performance and managerial behavior. However, the empirical literature predominately focuses on the effects of financial performance measures, despite the increased use of nonfinancial performance measures for incentive purposes (Banker et al. 2000). As a result, little 
evidence exists of the effects of using non-financial performance measures (Ittner and Larcker 1998b). One of the primary reasons for incorporating non-financial performance measures is that some of them are leading indicators of financial performance and provide managers with incentives to be long-term oriented (Ittner and Larcker 1998a). In the following, I focus on non-financial performance measures that reflect performance in the market, such as market share, market growth, and customer satisfaction. I focus on these non-financial performance measures because empirical research indicates that these measures are leading indicators of financial performance and should therefore provide managers with long-term incentives (Ittner and Larcker 1998a; Banker et al. 2000). For example, increasing customer satisfaction requires a manager to focus on providing service, which leads to repeat purchases and thus to improving long-term profitability (Hemmer 1996). This long-term orientation is relatively absent in the incentives provided by financial performance measures. For example, managers can increase financial performance in the short-term by accelerating sales or by providing sales pressure, which might be detrimental to long-term performance. The limited empirical evidence available is consistent with this argument and shows that the use of financial performance measures for incentive purposes leads managers to shorten their time-horizon (Merchant 1990; Van der Stede 2000). Although managerial short-term orientation is not dysfunctional in every circumstance (see e.g., Merchant and Manzoni 1989, 552), it is often harmful, and incorporating non-financial performance measures can reduce it. Given the agency theory prediction that managerial effort is determined by the incentives provided, the literature suggests that financial performance measures provide managers with short-term incentives, while non-financial performance measures provide managers with long-term incentives. This leads to the following hypotheses.

Hla: The use of financial performance measures for incentive purposes increases managerial short-term orientation. 
HIb: The use of non-financial performance measures for incentive purposes decreases managerial short-term orientation.

A similar line of reasoning applies to the difficulty of targets associated with the financial and non-financial performance measures. That is, given the implications of goal theory, more difficult financial (non-financial) performance targets increase (decrease) managerial short-term orientation. Once again, it is not clear a priori if this type of behavior increases or decreases long-term performance. For example, difficult financial performance targets might provide managers with incentives to be more efficient (functional) or to defer expenditures with respect to maintenance (dysfunctional) in order to reach their target. On the other hand, Ittner and Larcker (2000) state that non-financial performance measures are likely to be characterized by diminishing returns at higher performance levels. This implies that difficult non-financial performance targets provide managers with incentives to provide 'service', but 'too difficult' targets will lead to decreased performance because the associated costs with this increased 'service' will exceed the benefits. Although the effect of target difficulty on performance might not be strictly positive in the long-run, this does not alter the prediction that a more difficult financial (non-financial) performance target increases (decreases) managerial short-term orientation. Furthermore, under the assumption that firms make optimal decisions regarding the design of incentive systems, no performance effects are expected. As a result, I state the following hypotheses.

H2a: The difficulty of financial performance targets increases managerial short-term orientation.

H2b: The difficulty of non-financial performance targets decreases managerial short-term orientation.

Most of the incentive studies in accounting either examine performance measures and performance targets in isolation (e.g., Banker et al. 2000; Merchant and Manzoni 1989) or 
manipulate them to be uncorrelated (e.g., Chow 1983). However, it is very likely that firms set targets dependent on the degree to which the performance measures are used for incentive purposes. Simons (1988), for example, finds that targets are more difficult when these are also used for incentive purposes in a so-called budget-based compensation scheme. Other findings in the budgetary control literature provide similar results. For example, Merchant (1985), Dunk (1993), and Van der Stede (2000) all find that an increased emphasis on budgets for evaluation purposes decreases budgetary slack. In general, the empirical results indicate that an increased use of a particular performance measure for incentive purposes increases the difficulty of the target associated with that performance measure. Two explanations can be given for this positive relationship. First, given the rational expectations of superiors, performance targets will be more difficult when linked to compensation in order to offset the incentives given to subordinates to build in slack to maximize their compensation. Second, an increased use of performance measures for incentive purposes increases the likelihood of detecting and curtailing slack (Williamson 1964), which results in more difficult targets. Focusing on the effects of both financial and non-financial performance measures, the above findings lead to the following hypothesis.

H3: The use of financial (non-financial) performance measures for incentive purposes increases the difficulty of the financial (non-financial) performance target.

Finally, making rewards contingent on performance not only provides managers with incentives but it also increases the risk they have to bear. Increasing the difficulty of the performance target further increases this risk because it becomes more difficult to earn a 'bonus'. Agency theory states that the use of performance measures for incentive purposes depends on the trade-off between incentives and risk sharing and is affected by the risk aversion of the agent. Although Moers and Peek (2000) show that risk aversion affects the use 
of performance measures in CEO incentive contracts, it is unlikely that this prediction holds for subordinate managers. Most firms design incentive contracts for their subordinate managers based on characteristics of the firm and the individual's job because it is simply too costly to design incentive contracts based on personal characteristics. Since discretion is given to the superior in setting performance targets for individual managers, it might be more efficient to adjust the performance targets for the level of risk aversion. Merchant and Manzoni $(1989,550)$, for example, state that less difficult targets may be the outcome of the trade-off between incentives and risk sharing when performance measures are used for incentive purposes. If superiors indeed set less difficult performance targets to adjust for the risk imposed on the manager, then risk aversion plays a role in setting performance targets. Similarly, Young (1985) finds that risk averse managers build in more budget slack than nonrisk averse managers, probably as a response to uncertainty. Although superiors are likely to be aware of this behavior, they might allow 'some' slack in order to reduce the risk imposed on the manager. This implies that although the use of performance measures increases the difficulty of performance targets, as stated in hypothesis 3, this effect will be lower the higher the risk aversion of managers. The above argumentation leads to hypothesis 4 .

H4: The effect of the use of financial (non-financial) performance measures for incentive purposes on the difficulty of the financial (non-financial) performance target is less positive for higher levels of managerial risk aversion.

\section{RESEARCH METHOD}

To test the hypotheses developed in the previous section, I gathered data from multiple sources. The data sources used, consist of interviews, questionnaires, and proprietary archival data. Survey data are available for 114 managers employed in six firms, while proprietary 
data are available for 96 managers employed in five firms. This section presents details on the sample selection and data collection.

\section{Sample and data}

Data were collected from six firms as part of a larger study on incentive systems. Descriptive statistics of these firms are provided in Table 1. The HR manager of each firm selected the sample of respondents. In making the selection, the HR managers were given three criteria on which they should base their selection. First, the respondents should have managerial responsibilities, either as head of a functional department or as head of a division, business unit, or the like. To assure a minimum level of managerial responsibilities, the respondent's job design should have a score greater than 400 Hay-points $\frac{1}{3}$ Second, the respondent should have an annual bonus plan. Third, the respondent should have experienced at least one annual performance evaluation cycle. The HR managers were asked to select as many respondents as possible within the above three constraints. The selection by the HR managers resulted in 202 managers that were asked to participate in the study.

A questionnaire was developed for the purpose of this study. To maximize the response rate, I designed the questionnaire according to the guidelines of Dillman's (1978) Total Design Method. I pre-tested the questionnaire with seven academics and all six HR managers, which resulted in minor revisions of the questionnaire. Furthermore, I administered a follow-up by telephone and mail. Of the 202 questionnaires that were distributed, 114 were returned. This corresponds to an overall response rate of $56 \%$. This response rate is satisfactory and comparable to the response rates reported in previous accounting studies. Of the 114 questionnaires returned, nine have missing data. Because I use bootstrapped coefficient estimates and standard errors to calculate significance levels (Noreen 1989; Mooney and Duval 1993), I delete the nine questionnaires with missing data listwise ${ }^{4}$ A splitsample test at the firm-specific median response time indicates that there are no significant 
differences between early and late respondents for any of the variables, which suggests the absence of non-response bias.

Five firms provided archival data with respect to the annual bonus contract of the respondents, which were used to validate the survey-based measures of performance measure use. Four firms have uniform contracts for their managers with respect to the relative use of financial versus non-financial performance measures, although the number of performance measures in each category can vary between managers. However, I have no data with respect to the number of performance measures for each of the respondents in these four firms. One firm has manager-specific contracts, all of which were provided to me.$^{5}$ In total, archival data are available for 96 managers, while both survey and archival data are available for 87 managers.

\section{Measurement instruments}

Use of performance measures. The financial performance measures are defined as the 'traditional' financial performance measures, such as return-on-assets, net income, and cash flows. ${ }^{6}$ The non-financial performance measures are defined as those measures that reflect performance in the market, such as market share, market growth, and customer satisfaction. I focus on these type of non-financial performance measures because empirical research indicates that these measures are leading indicators of financial performance and should therefore provide managers with long-term incentives (Ittner and Larcker 1998a; Banker et al. 2000). The use of each type of performance measure for incentive purposes is measured using eight items. These items, listed in Table 2, relate to the use of each type of performance measure for (1) evaluation purposes, (2) monetary compensation, and (3) non-monetary rewards. A five-point fully anchored scale is used to indicate the importance of each type of performance measure for incentive purposes. Principal component analysis reveals one factor with an eigenvalue greater than one, explaining $57 \%$ of the total variance. I compute the 
construct 'use of performance measures' by summing and averaging the standardized scores of the eight items for, respectively, the financial performance measures and non-financial performance measures.

To test whether these survey-based constructs are consistent with the relative use of financial performance measures $(\% \mathrm{FPM})$ stated in the annual bonus contract, I split the sample into two groups of approximately equal size based on the median \%FPM. For each sub-sample, I compare the use of financial performance measures to the use of non-financial performance measures using a paired-sample t-test. The results, shown in Table 3, indicate that for the low-\%FPM sub-sample, the use of financial performance measures is significantly lower (one-tail $\mathrm{p}<0.01$ ) than the use of non-financial performance measures. For the high$\%$ FPM sub-sample, the use of financial performance measures is significantly higher (one-tail $\mathrm{p}<0.01)$ than the use of non-financial performance measures. These results provide some evidence that the survey-based measures are consistent with the weights stated in the annual bonus contract.

Previously, I stated that four firms have uniform annual bonus contracts with respect to the relative use of financial versus non-financial performance measures, although the number of performance measures in each category can vary. To test whether respondents within each firm report firm-specific incentives, i.e., corporate policy, rather than job-specific incentives, I examine the distribution of responses within each of these four firms. The results show that, although the mean response is consistent with corporate policy, there is no clustering of responses and there is significant variation in responses within each firm. These results suggest that the firms in question create job-specific incentives and that the respondents report these job-specific incentives. 
Insert Table 3 about here

Performance target difficulty. The instrument to measure the construct performance target difficulty is based on Kenis (1979) and contains five items. A five-point fully anchored scale is used to indicate, for each type of performance measure, the extent to which the performance targets are difficult to achieve and require a high amount of effort. Principal component analysis reveals one factor with an eigenvalue greater than one, explaining $53 \%$ of the total variance. I compute the construct performance target difficulty by summing and averaging the standardized scores of the five items for each type of performance measure. In a related study, I find that the correlation between this survey-based measure and archival data on the actual achievement of targets is significantly negative (one-tail $\mathrm{p}<0.05$ ), which indicates that the instrument measures what it is supposed to measure.

Managerial risk aversion. Comparable to Young (1985), I measure risk aversion by giving the respondent the option to choose between two alternative compensation contracts: (1) a fixed salary of 100,000 or (2) a fixed salary of 80,000 with a probability of receiving a bonus of 40,000. I ask the respondents to indicate how large the probability of receiving the bonus should be before they prefer alternative two to alternative one. The probability reflects the manager's risk aversion, where a higher probability means higher managerial risk aversion.

Managerial short-term orientation. The degree to which managers are short-term oriented is measured by taking the time-orientation instrument used by Merchant (1990) and Van der Stede (2000). The instrument asks respondents to indicate the percentage of their time that is devoted to activities of which the outcome will show up in the financial results within (1) one month or less, (2) one month to one quarter, (3) one quarter to one year, and (4) 
one year to five years. Managerial short-term orientation is computed by summing the percentages of the first three categories, i.e., effects within one year.

Table 4 provides the descriptive statistics of the measurement instruments used.

Insert Table 4 about here

\section{EMPIRICAL RESULTS}

The hypotheses 1 through 3 are graphically presented in Figure 1. Structural equation modeling with Maximum Likelihood estimates is used to test whether the data are consistent with Figure 1. Bootstrapped coefficient estimates and standard errors are used to determine statistical significance. Because of sample size limitations, I treat all variables in the model as observed variables rather than latent variables. Table 5 summarizes the results with respect to the effect of the financial and non-financial performance measures and performance targets on managerial short-term orientation.

Insert Figure 1 about here

\section{Hypotheses 1a-1b}

Hypotheses $1 \mathrm{a}$ and $1 \mathrm{~b}$ predict that the use of financial performance measures increases the manager's short-term orientation, while the use of non-financial performance measures decreases this type of behavior. The empirical results indicate that the use of both types of performance measures does not affect managerial short-term orientation. Therefore, hypotheses $1 \mathrm{a}$ and $1 \mathrm{~b}$ are not supported by the data, which seems to be inconsistent with previous research. 


\section{Hypotheses 2a and $2 b$}

Although the use of performance does not affect managerial short-term orientation, performance targets seem to have a significant impact. Table 5 shows that the difficulty of financial performance targets increases managerial short-term orientation (one-tail $\mathrm{p}<0.01$ ), while the difficulty of the non-financial performance targets decreases managerial short-term orientation (one-tail $\mathrm{p}<0.01$ ). As a result, the data provide strong support for hypotheses $2 \mathrm{a}$ and $2 b$.

Insert Table 5 about here

\section{Hypothesis 3}

Table 6 summarizes the results with respect to hypothesis 3, which states that the effect of the use of performance measures for incentive purposes on the difficulty of performance targets is positive. The empirical results indicate that the use of financial performance measures for incentive purposes is positively related to the difficulty of financial performance targets (one-tail $\mathrm{p}<0.01$ ). Furthermore, this positive relationship is also present with respect to the non-financial performance targets (one-tail $\mathrm{p}<0.01$ ). Therefore, hypothesis 3 is supported.

Insert Table 6 about here

\section{Hypothesis 4}

In order to test hypothesis 4 , I re-estimate the empirical model in Figure 1 and allow the relationship between the use of performance measures and target difficulty to be separately estimated for high risk averse managers and low risk averse managers. 
The results with respect to the relationship between the use of performance measures and performance target difficulty for high and low risk averse managers are presented in Table 7. For both groups of managers, the use of financial (non-financial) performance measures for incentive purposes increases the difficulty of the financial (non-financial) performance target (one-tail $\mathrm{p}<0.01$ ). Furthermore, the regression coefficients for the high risk aversion group are lower than those for the low risk aversion group. However, the difference between the regression coefficients is not significant for the non-financial performance measures and only marginally significant for the financial performance measures (one-tail $\mathrm{p}<0.10$ ). These results provide only weak support for the hypothesis 4 , which states that managerial risk aversion moderates the relationship between the use of performance measures for incentive purposes and the difficulty of performance targets.

Insert Table 7 about here

\section{Sensitivity analysis}

The finding that the use of financial performance measures and the use of nonfinancial performance measures for incentive purposes are not related to managerial shortterm orientation seems to be inconsistent with previous evidence (e.g., Merchant 1990). However, previous research neglects the effect of the difficulty of performance targets, which is positively related to the use of performance measures. To test if the results of previous research might be driven by target difficulty, I examine the effect of the use of performance measures on managerial short-term orientation without taking into account the effect of performance targets. The results (not reported) show that the use of financial performance measures is positively related to managerial short-term orientation (one-tail $\mathrm{p}<0.05$ ) and the use of non-financial performance measures is negatively related to managerial short-term 
orientation, though not significant. These findings provide some evidence that the results of previous research might be driven by performance target difficulty and that the use of performance measures only indirectly affects managerial short-term orientation.

I tested hypotheses 3 and 4 by analyzing the effect of financial performance measures and non-financial performance measures separately. However, the predictions stated in hypotheses 3 and 4 are identical for both types of performance measures. A more direct test of the hypotheses is to examine the effect of the use of performance measures in general on the difficulty of performance targets. Therefore, I treat each observation with respect to the use of financial (non-financial) performance measures and financial (non-financial) performance target difficulty as respectively an observation with respect to the use of performance measures and performance target difficulty. The results of the regression analysis, presented in Panel A of Table 8, indicate that the difficulty of performance targets and the use of performance measures for incentive purposes are positively related (one-tail $\mathrm{p}<0.01$ ), which is consistent with the findings of the original analysis and provides further support for hypothesis 3 .

Insert Table 8 about here

To test hypothesis 4 , I repeat the analysis for the low risk aversion group and the high risk aversion group. The results, presented in Panel B of Table 8, show that for both groups of managers, the relationship between the use of performance measures and the difficulty of performance targets is positive and significant (one-tail $\mathrm{p}<0.01$ ). Furthermore, the coefficient for the high risk aversion group is significantly lower than the coefficient for the low risk aversion group (one-tail $\mathrm{p}<0.05$ ). These findings provide stronger support for hypothesis 4 
than the results of the original analysis and suggest that superiors take the manager's risk aversion into account when setting performance targets.

\section{V.SUMMARY AND CONCLUSION}

This paper examines the effect of financial and non-financial performance measures and performance targets on managerial short-term orientation. I find that the use of financial and non-financial performance measures for incentive purposes do not affect the time orientation of managers in a direct manner. Rather they have an indirect effect working through the difficulty of performance targets. That is, the use of financial (non-financial) performance measures increases the difficulty of financial (non-financial) performance targets which subsequently increases (decreases) managerial short-term orientation. I further find that the relationship between the use of performance measures for incentive purposes and performance target difficulty is moderated by managerial risk aversion, which suggests that superiors take the risk aversion of the manager into account when setting performance targets.

The empirical results have several practical implications. First, incorporating certain performance measures in incentive contracts without emphasizing targets does not affect managerial behavior. Superiors have to set specific targets for the managers to shoot for and choose the difficulty of these targets dependent on how powerful they want the incentives to be. Thus, the type of performance measure used determines the 'direction' of effort, while the difficulty of the performance target determines the 'amount' of effort provided. In terms of 'what you measure is what you get', the performance measure determines 'what you get', while the performance target determines 'how much you get'. Second, if superiors want their subordinates to be more long-term oriented, then incorporating non-financial performance information in incentive systems can achieve this goal. Although not all non-financial performance measures provide long-term incentives, the type of performance measures used in this study, i.e., market-oriented measures, lengthen the manager's time horizon. Therefore, 
these measures increase the amount of time that managers spend on activities that affect future financial performance, which reduces the myopia problem. Finally, risk aversion affects the trade-off between incentives and risk sharing in the sense that fewer incentives can be given to risk averse managers. This means that it is more difficult to use incentive systems to promote certain types of behavior the higher the risk aversion of the manager. To make sure that these managers make congruent decisions, firms need to implement alternative control mechanisms.

As with any empirical study, this study has its limitations. I only examine the effect of incentive systems on managerial short-term orientation. Although this is an important consideration in designing incentive systems, these systems can affect other types of behavior, such as gaming, influence tactics, and job-related attitudes. Furthermore, the measurement of managerial short-term orientation does not allow any conclusions to be made about the importance of the manager's decisions (Van der Stede 2000). That is, if managers focus on the long-term, this does not necessarily mean that long-term performance is improved. Finally, all the firms that participated in this study are, or once were, clients of Hay Management Consultants. This non-random selection of firms makes it difficult to generalize the findings to firms that have not been 'assisted' by compensation consultants.

The empirical results provide several opportunities for future research. First, although the empirical results show that the difficulty of performance targets depends on the degree to which the performance measure is used for incentive purposes and the manager's risk aversion, the picture is far from complete. Since performance targets have significant incentive effects, future research should identify other factors that determine the difficulty of targets. Second, firms use different types of non-financial performance measures of which not all are leading indicators and provide managers with long-term incentives. An opportunity for future research is to examine which non-financial performance measures provide long-term 
incentives and which do not and what kind of incentives these latter performance measures do provide. Finally, the finding that incentive systems become less useful the higher the manager's risk aversion raises the question what alternative control tools firms use to promote goal congruent behavior. Almost no empirical evidence exists of how alternative control mechanisms can be used as substitutes and how these apply to managers who are highly risk averse. Future research should examine whether, for example, behavior monitoring, social control, or selection and training can substitute for the use of incentive systems. 


\section{REFERENCES}

Anderson, T.W. 1957. Maximum Likelihood Estimates for a Multivariate Normal Distribution When Some Observations Are Missing. Journal of the American Statistical Association 52: 200-203.

Banker, R.D., S. Lee, and G. Potter. 1996. A Field Study of the Impact of a PerformanceBased Incentive Plan. Journal of Accounting and Economics 21: 195-226.

— G. Potter, and D. Srinivasan. 2000. An Empirical Investigation of an Incentive Plan that Includes Nonfinancial Performance Measures. The Accounting Review 75: 65-92.

Chow, C.W. 1983. The Effects of Job Standard Tightness and Compensation Scheme on Performance: An Exploration of Linkages. The Accounting Review 58: 667-685.

Dillman, D.A. 1978. Mail and Telephone Surveys: The Total Design Method. New York: John Wiley \& Sons.

Dunk, A.S. 1993. The Effect of Budget Emphasis and Information Asymmetry on the Relation between Budgetary Participation and Slack. The Accounting Review 68: 400410.

Feltham, G.A., and J. Xie. 1994. Performance Measure Congruity and Diversity in Multi-Task Principal/Agent Relations. The Accounting Review 69: 429-453.

Flannery, T.P., D.A. Hofrichter, and P.E. Platten. 1996. People, Performance, and Pay: Dynamic Compensation for Changing Organizations. The Hay Group: The Free Press.

Gaver, J.J., K.M. Gaver, and J.R. Austin. 1995. Additional Evidence on Bonus Plans and Income Management. Journal of Accounting and Economics 19: 3-28.

Grice, J.W., and R.J. Harris. 1998. A Comparison of Regression and Loading Weights for the Computation of Factor Scores. Multivariate Behavioral Research 33: 221-247. 
Guidry, F., A.J. Leone, and S. Rock. 1998. Earnings-Based Bonus Plans and Earnings Management by Business-Unit Managers. Journal of Accounting and Economics 26: 113-142.

Healy, P.M. 1985. The Effect of Bonus Schemes on Accounting Decisions. Journal of Accounting and Economics 7: 85-107.

Hemmer, T. 1996. On the Design and Choice of 'Modern' Management Accounting Measures. Journal of Management Accounting Research 8: 87-116.

Hirst, M.K., and P.W. Yetton. 1999. The Effects of Budget Goals and Task Interdependence on the Level and Variance in Performance: A Research Note. Accounting, Organizations and Society 24: 205-216.

Holmström, B., and P. Milgrom. 1991. Multitask Principal-Agent Analyses: Incentive Contracts, Asset Ownership, and Job Design. Journal of Law, Economics and Organization 7: 24-52.

Holthausen, R.W., D.F. Larcker, and R.G. Sloan. 1995. Annual Bonus Schemes and the Manipulation of Earnings. Journal of Accounting and Economics 19: 29-74.

Ittner, C.D., and D.F. Larcker. 1998a. Are Nonfinancial Measures Leading Indicators of Financial Performance? An Analysis of Customer Satisfaction. Journal of Accounting Research 36: 1-35.

— and - 1998b. Innovations in Performance Measurement: Trends and Research Implications. Journal of Management Accounting Research 10: 205-238.

— , and — 2000. Assessing Empirical Research in Managerial Accounting: A ValueBased Management Perspective. Journal of Accounting and Economics (forthcoming).

Kaplan, R.S., and D.P. Norton. 2001. Transforming the Balanced-Scorecard from Performance Measurement to Strategic Management: Part I. Accounting Horizons 15: 87-104. 
Kenis, I. 1979. Effects of Budgetary Goal Characteristics on Managerial Attitudes and Performance. The Accounting Review 54: 707-721.

Locke, E.A., and G.P. Latham. 1990. A Theory of Goal Setting and Task Performance. Englewood-Cliffs: Prentice-Hall.

Merchant, K.A. 1985. Budgeting and the Propensity to Create Budgetary Slack. Accounting, Organizations and Society 10: 201-210.

—. 1989. Rewarding Results: Motivating Profit Center Managers. Boston: Harvard Business School Press.

- 1990. The Effects of Financial Controls on Data Manipulation and Management Myopia. Accounting, Organizations and Society 15: 297-313.

— , and J.F. Manzoni. 1989. The Achievability of Budget Targets in Profit Centers: A Field Study. The Accounting Review 64: 539-558.

—, W.A. Van der Stede, and L. Zheng. 2000. Disciplinary Constraints on the Advancement of Knowledge: The Case of Organizational Incentive Systems. Working Paper, University of Southern California.

Moers, F. and E. Peek. 2000. An Empirical Analysis of the Role of Risk Aversion in Executive Compensation Contracts. Working Paper, Maastricht University.

Mooney, C.Z., and R.D. Duval. 1993. Bootstrapping: A Nonparametric Approach to Statistical Inference. Sage University Paper Series on Quantitative Applications in the Social Sciences. Newbury Park, CA: Sage.

Noreen, E.W. 1989. Computer-Intensive Methods for Testing Hypotheses. New York: John Wiley \& Sons.

Simons, R. 1988. Analysis of the Organizational Characteristics Related to Tight Budget Goals. Contemporary Accounting Research 5: 267-283. 
Van der Stede, W.A. 2000. The Relationship between Two Consequences of Budgetary Controls: Budgetary Slack Creation and Managerial Short-Term Orientation. Accounting, Organizations and Society 25: 609-622.

Wallace, J.S. 1997. Adopting Residual Income-Based Compensation Plans: Do You Get What You Pay for? Journal of Accounting and Economics 24: 275-300.

Williamson, O.E. 1964. The Economics of Discretionary Behavior: Managerial Objectives in a Theory of the Firm. Englewood-Cliffs: Prentice-Hall.

Young, S.M. 1985. Participative Budgeting: The Effects of Risk Aversion and Asymmetric Information on Budgetary Slack. Journal of Accounting Research 23: 829-842. 
TABLE 1

Descriptive Statistics of Participating Firms

\begin{tabular}{llrr} 
Firm & Activity & \# of employees \\
\cline { 1 - 1 } A & Provision of financial services & 1,690 \\
B & Trade of machinery and provision of technical services & 12,207 \\
C & Provision of life and indemnity insurance & 1,275 \\
D & Trade of pharmaceutical products & 401 \\
E & Production of food products & 7,482 \\
F & Financial leasing & 354 \\
\hline
\end{tabular}


TABLE 2

Questionnaire Items Related to the Measurement of the Use of Performance Measures for Incentive purposes

How much importance does your superior attach to xxx performance measures in ${ }^{a}$
a. ... the evaluation of your performance
b. ... periodic performance-reports
c. ... officially rating your performance
d. ... periodic discussions with you
e. ... determining your salary increases
f. ... determining your annual bonus
g. ... increasing your chance of promotion
h. ... increasing your authority within the organization

a Items are measured on a five-point fully anchored scale ranging from 'no importance' to 'very high
importance'. 
TABLE 3

Paired Sample T-test with respect to Differences between the Use of Financial and Non-financial Performance Measures for Groups of Low and High Relative Reliance on Financial Performance Measures in the Annual Bonus Contract

\begin{tabular}{|c|c|c|c|c|}
\hline \multirow[b]{3}{*}{ Performance measure } & \multicolumn{4}{|c|}{$\begin{array}{c}\text { Relative Reliance on Financial Performance Measures in } \\
\text { Annual Bonus Contract }\end{array}$} \\
\hline & \multicolumn{2}{|c|}{ Low } & \multicolumn{2}{|c|}{ High } \\
\hline & Mean use & Difference & Mean use & Difference \\
\hline Financial & -0.375 & & 0.388 & \\
\hline Non-financial & -0.044 & $-0.331 * * *$ & -0.177 & $0.565^{* * *}$ \\
\hline
\end{tabular}

$* * *, * *, *, \dagger$ is significant at respectively the $1 \%, 2 \frac{1}{2} \%, 5 \%$, and $10 \%$ level (one-tailed). 
TABLE 4

Descriptive Statistics

\begin{tabular}{|c|c|c|c|c|}
\hline Variable & Mean & $\begin{array}{l}\text { Standard } \\
\text { deviation }\end{array}$ & Actual range & $\begin{array}{l}\text { Cronbach } \\
\text { alpha }\end{array}$ \\
\hline $\begin{array}{l}\text { Use of Financial } \\
\text { Performance Measures }\end{array}$ & 0 & 0.74 & $-2.11-1.59$ & 0.88 \\
\hline $\begin{array}{l}\text { Use of Non-financial } \\
\text { Performance Measures }\end{array}$ & 0 & 0.77 & $-2.32-1.49$ & 0.90 \\
\hline $\begin{array}{l}\text { Difficulty of Financial } \\
\text { Performance Targets }\end{array}$ & 0 & 0.74 & $-1.85-1.29$ & 0.79 \\
\hline $\begin{array}{r}\text { Difficulty of Non-financial } \\
\text { Performance Targets }\end{array}$ & 0 & 0.69 & $-2.21-1.36$ & 0.73 \\
\hline Managerial Risk Aversion & $66.30 \%$ & 15.13 & $30-100 \%$ & - \\
\hline $\begin{array}{c}\text { Managerial Short-Term } \\
\text { Orientation } \\
\end{array}$ & $68.92 \%$ & 24.55 & $3-100 \%$ & - \\
\hline
\end{tabular}


TABLE 5

Empirical Results of the Effects of Performance Measures and Performance Targets on Managerial Short-Term Orientation

Variable

Use of Financial Performance Measures

Use of Non-financial Performance Measures

Difficulty of Financial Performance Targets

Difficulty of Non-financial Performance Targets

Squared Multiple Correlation

\section{Managerial Short-Term Orientation}

2.30

2.81

$13.06 * * *$

$-11.08 * * *$

0.24

$* * *, * *, *, \dagger$ is significant at respectively the $1 \%, 2 \frac{1}{2} \%, 5 \%$, and $10 \%$ level (one-tailed) using coefficient estimates and standard errors generated from 500 random bootstrap samples (with replacement).

Parameters are maximum likelihood estimates. 
TABLE 6

Empirical Results of the Effect of the Use of Performance Measures for Incentive Purposes on the Difficulty of Performance Targets

\begin{tabular}{lcc} 
Variable & $\begin{array}{c}\text { Difficulty of } \\
\text { Financial } \\
\text { Performance } \\
\text { Targets }\end{array}$ & $\begin{array}{c}\text { Difficulty of } \\
\text { Non-financial } \\
\text { Performance } \\
\text { Targets }\end{array}$ \\
\cline { 1 - 3 } $\begin{array}{l}\text { Use of Financial Performance Measures } \\
\text { Use of Non-financial Performance Measures }\end{array}$ & $0.50 * * *$ & $0.31 * * *$ \\
Squared Multiple Correlation & 0.25 & 0.12 \\
$\begin{array}{l}* * *, * *, *, \dagger \text { is significant at respectively the } 1 \%, 2 \frac{1}{2} \%, 5 \%, \text { and } 10 \% \text { level (one-tailed) using coefficient } \\
\text { estimates and standard errors generated from } 500 \text { random bootstrap samples (with replacement). } \\
\text { Parameters are maximum likelihood estimates. }\end{array}$ & \\
\hline
\end{tabular}




\section{TABLE 7}

Empirical Results with respect to the Effect of Managerial Risk Aversion on the Relationship between the Use of Financial

(Non-financial) Performance Measures for Incentive Purposes and the Difficulty of Financial (Non-financial) Performance Targets

Panel A: Financial performance and managerial risk aversion

Variable

Use of Financial Performance Measures

Squared Multiple Correlation

$\frac{\text { Low risk aversion }}{0.60^{* * *}}$

0.37
Difficulty of Financial Performance Targets

\begin{tabular}{cc} 
High risk aversion & Difference \\
\cline { 3 - 3 } $0.35^{* * *}$ & $0.25 \dagger$
\end{tabular}

0.14

Panel B: Non-financial performance and managerial risk aversion

Difficulty of Non-financial Performance Targets

Variable

Use of Non-financial Performance Measures

Squared Multiple Correlation

\begin{tabular}{c}
\hline Low risk aversion \\
$0.38^{* * *}$ \\
0.16
\end{tabular}

Difference

0.09

***, **, *, † is significant at respectively the $1 \%, 2 \frac{1}{2} \%, 5 \%$, and $10 \%$ level (one-tailed) using coefficient estimates and standard errors generated from 500 random bootstrap samples (with replacement).

Parameters are maximum likelihood estimates. 


\section{TABLE 8}

Empirical Results with respect to the Effect of Managerial Risk Aversion on the Relationship between the

Use of Performance Measures for Incentive Purposes and the Difficulty of Performance Targets for the Total Sample and Subgroups of Managerial Risk Aversion

Panel A: Total sample

Variable

Use of Performance Measures

Squared Multiple Correlation

Panel B: Subgroups of managerial risk aversion

\section{Variable}

Use of Performance Measures

Squared Multiple Correlation

\section{Difficulty of Performance Targets \\ $0.40 * * *$}

0.18

Difficulty of Performance Targets

\begin{tabular}{ccc}
\hline Low risk aversion & $\frac{\text { High risk aversion }}{0.32^{* * *}}$ & Difference \\
\cline { 3 - 3 } $0.51^{* * *}$ & 0.13 & $0.19^{*}$ \\
0.27 &
\end{tabular}

***, **, * $\dagger$ is significant at respectively the $1 \%, 2 \frac{1}{2} \%, 5 \%$, and $10 \%$ level (one-tailed) using coefficient estimates and standard errors generated from 500 random bootstrap samples (with replacement).

Parameters are maximum likelihood estimates. 
FIGURE 1

Empirical model

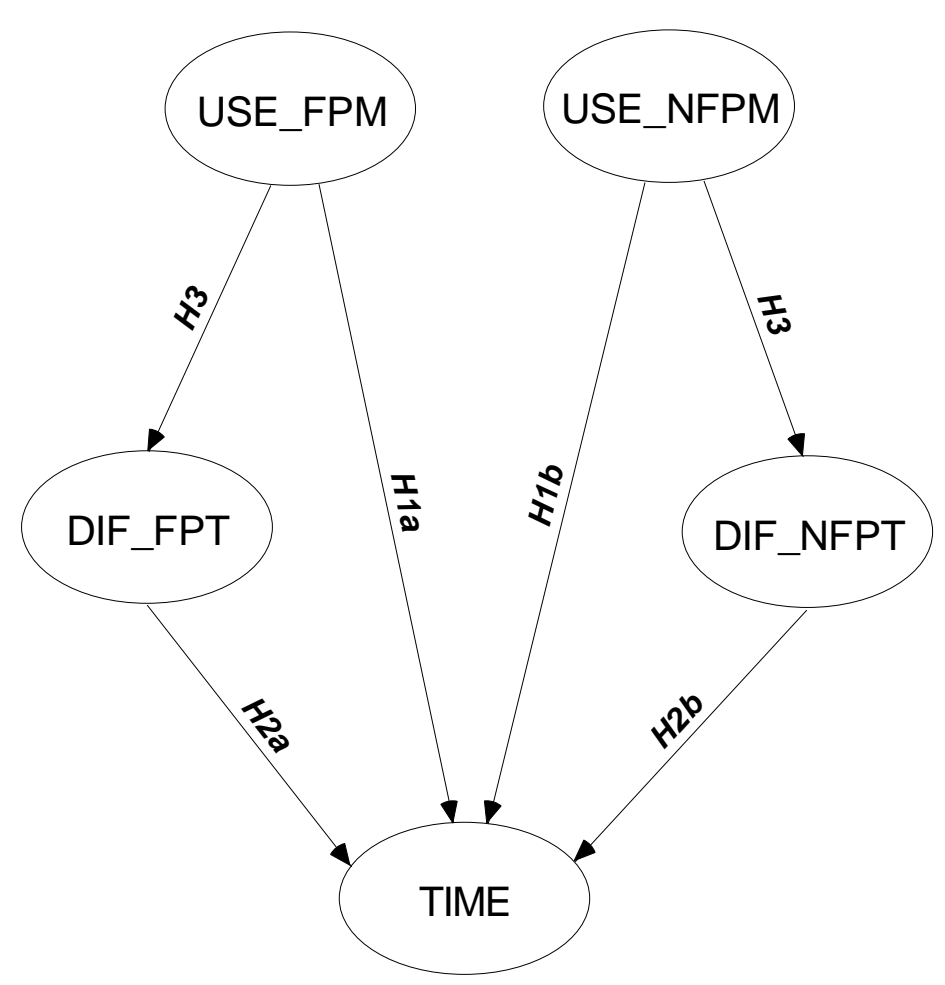

Notes:

${ }^{a}$ USE_FPM = use of financial performance measures;

USE_NFPM = use of external non-financial performance measures;

DIF_FPT $=$ difficulty of financial performance target;

DIF_NFPT $=$ difficulty of external non-financial performance target;

TIME = managerial short-term orientation . 


\section{Endnotes:}

${ }^{1}$ No goals can be interpreted as implicit 'do your best' goals.
${ }^{2}$ Budgetary slack leads to a higher probability of achieving the budget. Therefore, budgetary slack and budget difficulty are negatively correlated.

${ }^{3}$ The Hay-points are based on the Hay Guide Chart Profile Method, a system that compares the value of jobs based on multiple factors such as accountability and know-how (Flannery et al. 1996, 20). A score greater than 400 relates to higher-level personnel.

${ }^{4}$ I also compute full information maximum likelihood (FIML) estimates (Anderson 1957) using all 114 observations. The results (not reported) are identical to those presented in this paper.

${ }^{5}$ The archival data can be linked to the questionnaire data through codes. Each questionnaire contains a unique code that is printed on the final page of the questionnaire. The HR manager of each firm provides the archival data mentioning the codes instead of the respondent's name, which does not violate the anonymity principle.

${ }^{6}$ All examples presented with respect to each type of performance measure are measures actually used for incentive purposes by the participating firms.

${ }^{7}$ In computing all constructs with multiple items, I use unit-weighted average standardized scores because these have preferred psychometric properties relative to regression estimates of factor scores (Grice and Harris 1998).

${ }^{8}$ I split the sample into two groups of approximately equal size based on the median level of risk aversion. 